\title{
Efektifitas penyuluhan antara metode ceramah dengan pengisian teka teki silang terhadap pengetahuan dan tingkat kebersihan gigi dan mulut murid MTS Ar-Raudhatul Islamiyah, Mempawah
}

\author{
Halimah a, ${ }^{*}$, Rita Herlina ${ }^{\text {b, I }}$, M. Ibraar Ayatullah ${ }^{\text {b, } 2}$ \\ a Jurusan Keperawatan Gigi, Poltekkes Kemenkes Pontianak \\ b Jurusan Keperawatan Gigi, Poltekkes Kemenkes Kupang \\ ${ }^{1}$ halimahmdsc@gmail.com*; ritaherlina727@gmail.com; mibraarayatullah@gmail.com \\ *korespondensi penulis
}

\begin{tabular}{l}
\hline Informasi artikel \\
\hline Sejarah artikel: \\
Diterima \\
Revisi \\
Dipublikasikan \\
\hline
\end{tabular}

ABSTRAK

Pendidikan kesehatan gigi dan mulut yang diberikan melalui penyuluhan, sebaiknya menggunakan salah satu dari berbagai macam metode penyuluhan yang ada untuk mempermudah

Kata kunci:

Penyuluhan

Ceramah

Teka-teki silang penerimaan informasi. Penyampaikan materi penyuluhan dalam pembelajaran kesehatan gigi dan mulut ini dibutuhkan suatu media. Media pembelajaran dalam pendidikan kesehan gigi dan mulut salah satunya dengan penyuluhan menggunakan media teka-teki silang merupakan salah satu alternatif yang dapat digunakan sebagai media penyuluhan. Media teki-teki silang merupakan suatu media permainan yang dapat digunakan sebagai media penyuluhan dalam pendidikan kesehatan gigi dan mulut dan dapat menarik minat peserta penyuluhan. Tujuan penelitian ini adalah untuk mengetahui Efektifitas Penyuluhan antara metode ceramah dengan Pengisian teka teki silang terhadap pengetahuan dan tingkat kebersihan gigi dan mulut pada Siswa/i Kelas VIII dan VII MTs Arraudhatul Islamiyah Kabupaten Mempawah Tahun 2018. Populasi pada penelitian adalah berjumlah 74 orang. Sampel penelitian diambil dengan purposif dengan kriteria tertentu. Kelompok I berjumlah 30 orang dan dan subyek penelitian II berjumlah 30 orang. Penelitian yang digunakan adalah penelitian eksperimental semu dengan rancangan penelitian Pre-Post observasi, uji statistik Wilcoxon Signed Rannks Test untuk mengukur pengetahuan sebelum dan sesudah perlakuan dan paired t-test, untuk mengukur tingkat kebersihan gigi dan mulut sebelum dan sesudah perlakuan, Uji Efektifitas dengan persen untuk mengukur efektifitas antara penyuluhan dengan ceramah dan pengisian tekateki silang. Dengan alat ukur kuesioner untuk mengukur pengetahuan dan pemeriksaan indeks PHP untuk mengukur tingkat kebersihan gigi dan mulut. Hasil penelitian bahwa pengetahuan dan tingkat kebersihan gigi dan mulut baik penyuluhan dengan cermah maupun pengisian teka-teki silang antara sebelum dan sesudah terdapat perbedaan yang bermakna $p<0,05$. Penyuluhan dengan pengisian teka-teki silang lebih efektif meningkatkan pengetahuan dengan selisih rata-rata 22,0\% sedangkan Penyuluhan ceramah 20,1\%. Peningkatan kebersihan gigi dan mulut kelompok teka-teki silang $68,2 \%$ sedangkan ceramah $54,4 \%$. 
Key word:

Counseling

Lecture method

Crossword puzzle

\section{ABSTRACT}

The effectiveness of counseling between the lecture methods and filling in crossword puzzles to the knowledge and level of dental hygiene and mouth of the students of MTs Ar-raudhatul Islamiyah, Mempawah. Dental and oral health education provided through counseling, you should use one of the various types of counseling methods available to facilitate the acceptance of information. The media presenters of counseling materials in learning dental and oral health are needed. One of the learning media in dental and oral health education is counseling using crossword media as an alternative that can be used as an extension media. Media crossword puzzle is a game media that can be used as an extension media in dental and oral health education and can attract the interest of counseling participants. The purpose of this study was to determine the effectiveness of counseling between lecture methods by filling in crossword puzzles on the knowledge and level of dental and oral hygiene in Class VIII and VII students of Mempawah District Arraudhatul Islamiyah MTs in 2018. The population in the study was 74 people. The research sample was taken purposively with certain criteria. Group I numbered 30 people and research subjects II amounted to 30 people. The research used was quasi-experimental research with Pre-Post observation research design, Wilcoxon Signed Rannks Test statistical test to measure knowledge before and after treatment and paired t-test, to measure the level of dental and oral hygiene before and after treatment, Effectiveness Test with percent to measure the effectiveness of counseling and filling in crossword puzzles. With a measuring instrument questionnaire to measure knowledge and PHP index checks to measure the level of dental and oral hygiene. The results of the study that knowledge and level of dental and oral hygiene were both counseling with refinement and filling in crossword puzzles between before and after there were significant differences $p<0.05$. Counseling by filling in crosswords is more effective in increasing knowledge with an average difference of $22.0 \%$ while lecture counseling is $20.1 \%$. The improvement of dental and oral hygiene of the crossword group was $68.2 \%$ while the lecture was $54.4 \%$.

This is an openaccess article under the CC-BY-SAlicense.

\section{Pendahuluan}

Rongga mulut dan gigi yang sehat senantiasa bersih dari plak. Plak gigi adalah merupakan deposit lunak yang melekat erat pada permukaan gigi, terdiri atas mikroorganisme yang berkembang biak di atas suatu matrik interseluler jika seseorang mengabaikan kebersihan gigi dan mulutnya1 dan plak adalah penyebab timbulnya radang pada gusi (gingivitis) dan jaringan pendukung gigi lainnya. Jika dibiarkan lebih lanjut, akan menyebabkan gigi berlubang. ${ }^{2}$

Menurut data dari Riset Kesehatan Dasar (RISKESDAS) tahun 2013, pada indeks DMF$\mathrm{T}$ terdapat 5 provinsi dengan angka terbesar yaitu Bangka Belitung 8,5, Kalimantan Selatan 7,2, Kalimantan Barat 6,2, Sulawesi Selatan 6,0 , dan DI Yogyakarta 5,9.Dilihat dari hasil 
RISKESDAS 2013, untuk daerah Kalimantan Barat, skor DMF-T anak usia 12 tahun sebesar 6,2 yang artinya terjadi kerusakan gigi sebanyak lebih kurang 6 gigi pada setiap anak. ${ }^{3}$

Kesehatan gigi dan mulut dapat dicapai dengan cara menjaga kebersihan rongga mulut. Pendidikan kesehatan pada hakikatnya adalah suatu kegiatan atau usaha untuk menyampaikan pesan kesehatan kepada masyarakat, kelompok dan individu. Masyarakat, kelompok dan individu yang mendapat pesan tersebut diharapkan dapat memperoleh pengetahuan tentang kesehatan yang lebih baik, sehingga diharapkan dengan pengetahuan tersebut akan terjadi perubahan perilaku kesehatan. ${ }^{4}$ Pendidikan kesehatan merupakan program yang direncanakan untuk sasaran agar mau belajar tentang kesehatan, dengan memberikan informasi tentang kesehatan yang dapat mengeksplorasikan nilai dan sikap dan mempelajari keterampilan-keterampilan yang memungkinkan untuk perubahan perilaku ke arah yang lebih baik tentang kesehatan. ${ }^{5}$ Pendidikan kesehatan dilakukan sebagai upaya untuk meningkatkan pengetahuan, sikap dan tindakan sehingga diharapkan akan terjadi perubahan perilaku. Proses pendidikan kesehatan yang menuju pada tercapainya tujuan pendidikan yaitu untuk perubahan perilaku dapat dilakukan dengan beberapa metode antara lain metode ceramah, diskusi, demontrasi, simulasi dan lain-lain. ${ }^{6}$ Dalam proses pendidikan, penggunaan metode yang baik adalah metode yang bervariasi atau metode kombinasi dari beberapa metode, dan sesuai dengan materi yang disampaikan, sehingga akan mendapatkan hasil yang efektif. ${ }^{7}$

Metode ceramah adalah salah satu cara pendidikan kesehatan yang didalamnya menjelaskan sesuatu secara lisan. Penelitian Setyowati tahun 2011 menunjukkan bahwa terdapat perbedaan pengaruh pendidikan kesehatan gigi menggunakan metode ceramah dengan metode demonstrasi dalam meningkatkn pengetahun anak. Metode ceramah lebih efektif dibandingkan demonstrasi dalam meningkatkan pengetahuan tentang kesehatan gigi dan mulut pada siswa kelas Vdi SD Soka Kecamatan Poncowarno Kabupten Kebumen. ${ }^{8}$ Belajar tidak cukup hanya mendengar dan melihat tetapi harus dengan melakukan aktivitas yang lainnya diantaranya membaca, bertanya, menjawab, berpendapat, mengerjakan tugas, menggambar, mengkomunikasikan, presentasi, diskusi, menyimpulkan dan memanfaatkan peralatan. Penyampaikan materi penyuluhan dalam pembelajaran kesehatan gigi dan mulut ini dibutuhkan suatu media. Media pembelajaran adalah segala sesuatu (alat/sarana) yang dapat berfungsi sebagai saluran/perantara komunikasi dalam kegiatan pendidikan agar dapat berlangsung secara efisien dan efektif.

Media pembelajaran dalam pendidikan kesehan gigi dan mulut salah satunya dengan penyuluhan menggunakan media teka-teki silang merupakan salah satu alternatif yang dapat digunakan sebagai media penyuluhan. Media teki-teki silang merupakan suatu media cetak yang dapat digunakan sebagai media penyuluhan dalam pendidikan kesehatan gigi dan mulut.

Berdasarkan hasil penelitian sebelumnya yang dilakukan Wasgito tahun 2014 bahwa dengan menggunakan media teka-teki silang dalam proses pembelajaran siswa kelas VII SMP Negeri 2 Kalianget dapat meningkatkan keaktifan belajar siswa. Hasil test belajar siswa dengan menggunakan media teka-teki silang yang diuji cobakan dikelas menunjukkan kriteria "sangat baik" dengan rata-rata nilai kelas 84,7. 9

Berdasarkan latar belakang tersebut di atas bahwa penyuluhan dengan metode ceramah yaitu dengan responden hanya mendengar dan penyuluhan dengan media pengisian teka teki silang dengan melihat dan mengerjakan sehingga dapat meningkatkan pengetahuan dan meningkatkan keaktifan belajar siswa. Penelitian ini dilakukan pada siswa MTs. Ar- 
Raudhatul Islamiyah, Kabupaten Mempawah. Karena di MTs tersebut hanya penjaringan yang pernah dilakukan pada murid pertama masuk yaitu di kelas VII dari Tenaga Kesehatan wilayah binaannya. Dan pada masa usia sekolah merupakan masa untuk meletakkan landasan kokoh bagi terwujudnya manusia yang berkualitas dan kesehatan merupakan faktor penting yang menentukan kualitas sumber daya manusia. Pada usia sekolah merupakan kelompok rawan terhadap masalah kesehatan gigi, dan pada usia sekolah sangat peka untuk menanamkan pengertian dan kebiasaan karena kesehatan sangat berpengaruh terhadap prestasi belajar sehingga pendidikan melalui sekolah sangat efektif merubah perilaku dan kebiasaan-kebiasaan tentang kesehatan.

\section{Bahan dan Metode Penelitian}

Jenis penelitian yang digunakan adalah penelitian eksperimental semu dengan menggunakan rancangan penelitian pre dan post observasional yaitu dengan cara membandingkan antara kelompok perlakuan penyuluhan metode ceramah dengan kelompok perlakuan media teka-teki silang. Penelitian dilakukan pada bulan Agustus s/d September 2018 di MTs Ar-Raudatul Islamiyah Kabupaten Mempawah Provinsi Kalimantan Barat. Populasi pada penelitian ini adalah seluruh siswa kelas VIII dan VII MTs Arraudatul Islamiyah Kabupaten Mempawah sebanyak 74 siswa. Penentuan sampel pada penelitian ini menggunakan tehnik purposive sampling yaitu kelas VIII dan VII sebanyak 60 orang. Subyek penelitian dibagi dalam dua kelompok yaitu : Kelompok perlakuan I yang diberi penyuluhan metode ceramah sebanyak 15 orang kelas VIII dan 15 orang kelas VII dan kelompok perlakuan II dengan pengisian teka teki silang sebanyak 15 orang kels VIII dan 15 orang kelas VII MTs Arraudatul Islamiyah Kabupaten Mempawah dengan Kriteria Inklusi dalam penelitian ini adalah: a) Responden hadir dikelas saat dilakukan pengambilan data, b). Responden yang bersedia menjadi subyek penelitian,c). Responden dengan tidak ada peradangan baik gingiva maupun periodontal sedangkan kriteria ekslusi dalam penelitian ini adalah: a). Responden tidak disiplin pada saat pengambilan data, b). Gigi indeks maupun gigi pengganti kurang dari 2 gigi.

\section{Hasil dan Pembahasan}

Tabel 1. Hasil Analisis Uji Wilcoxon Signed Rank Perbedaan Pengetahuan Sebelum dan sesudah Penyuluhan Metode Ceramah

\begin{tabular}{cccc}
\hline \multirow{2}{*}{ Kelompok } & $\mathrm{N}$ & Mean Rank & \multicolumn{2}{c}{ Hasil Uji Statistik } \\
Sesudah & 30 & 0,00 & \multirow{2}{*}{0,000} \\
\hline Sebelum & 30 & 14.00 &
\end{tabular}

Tabel 1 Uji Wilcoxon Signed Rank pengetahuan sebelum dan sesudah penyuluhan dengan ceramah menunjukkan perbedaan yang signifikan dengan nilai $p=0,000(p<0,05)$ 
Tabel 2. Hasil Analisis Uji Wilcoxon Signed Rank Perbedaan Pengetahuan Sebelum dan sesudah diberikan Penyuluhan dengan Pengisian Teka-Teki Silang

\begin{tabular}{ccccc}
\hline Kelompok & N & Mean Rank & Hasil Uji Statistik \\
Sesudah & 30 & 0,00 & Sig. \\
\hline Sebelum & 30 & 15.00 & 0,000 \\
\hline
\end{tabular}

Signifikan $\mathrm{p}<0,005$

Tabel 2 Uji Wilcoxon Signed Rank pengetahuan sebelum dan sesudah diberikan penyuluhan dengan Pengisian Teka-Teki Silang terdapat perbedaan yang signifikan dengan nilai $p=0,000(p<0,05)$

Tabel 3. Hasil Uji Paired Samples Test Perbedaan Tingkat Kebersihan Gigi dan Mulut Sebelum dan sesudah diberikan Penyuluhan Metode Ceramah

\begin{tabular}{|c|c|c|c|c|c|}
\hline \multirow{2}{*}{ Kelompok } & \multirow{2}{*}{$\mathrm{N}$} & \multirow{2}{*}{ Rerata \pm SD } & \multicolumn{3}{|c|}{ Hasil Uji Statistik } \\
\hline & & & $\mathrm{T}$ & Df & Sig. \\
\hline Sebelum & 30 & $22,00 \pm 4,712$ & 10456 & 29 & 0 \\
\hline Sesudah & 30 & $10,00 \pm 6,136$ & 10,436 & 29 & 0,000 \\
\hline
\end{tabular}

Tabel 3 terlihat bahwa terdapat perbedaan rata-rata indeks plak sebelum perlakuan 22,00 dan sesudah perlakuan 10,00 . Dilihat dari $p$ yaitu $0,000 \quad(p<0,05)$ maka dapat disimpulkan terdapat perbedaan yang bermakna peningkatan kebersihan kesehatan gigi dan mulut (penurunan indeks plak setelah diberikan penyuluhan menggunakan Metode ceramah)

Tabel 4. Hasil Uji Paired Samples Test Perbedaan Tingkat Kebersihan Gigi dan Mulut Sebelum dan sesudah diberikan Penyuluhan Metode Pengisian Teka-teki Silang

\begin{tabular}{|c|c|c|c|c|c|}
\hline \multirow{2}{*}{ Kelompok } & \multirow{2}{*}{$\mathrm{N}$} & \multirow{2}{*}{ Rerata \pm SD } & \multicolumn{3}{|c|}{ Hasil Uji Statistik } \\
\hline & & & $\mathrm{T}$ & Df & Sig. \\
\hline Sebelum & 30 & $20,30 \pm 4,324$ & \multirow{2}{*}{15,837} & \multirow{2}{*}{29} & \multirow{2}{*}{0,000} \\
\hline Sesudah & 30 & $6,533 \pm 4,477$ & & & \\
\hline
\end{tabular}

Tabel 4 terlihat bahwa terdapat perbedaan rata-rata indeks plak sebelum perlakuan 20,300 dan sesudah perlakuan 6, 533 . Dilihat dari $p$ yaitu $0,000(p<0,05)$ maka dapat disimpulkan terdapat perbedaan yang bermakna peningkatan kebersihan kesehatan gigi dan mulut (penurunan indeks plak setelah diberikan penyuluhan menggunakan Metode pengisian Teka-teki Silang) 
Tabel 5. Hasil Uji Efektifitas dengan menggunakan Persen Test Perbedaan Selisih Pengetahuan dan Tingkat Kebersihan Gigi dan Mulut setelah diberikan Penyuluhan Metode Ceramah dan Pengisian Teka-teki Silang

\begin{tabular}{ccc}
\hline Variabel/ Kelompok & $\begin{array}{c}\text { Ceramah } \\
(\%)\end{array}$ & $\begin{array}{c}\text { Teka-teki Silang } \\
(\%)\end{array}$ \\
\hline Pengetahuan & 20,1 & 22,0 \\
\hline $\begin{array}{c}\text { Kebersihan Gigi dan } \\
\text { Mulut }\end{array}$ & 54,4 & 68,2 \\
\hline
\end{tabular}

Tabel 5 menunjukkan bahwa terdapat perbedaan pengetahuan antara pemberian penyuluhan ceramah yaitu 20,1 \% dan penyuluhan dengan pengisian Tek-teki Silang 22,1\%. Sedangkan Tingkat kebersihan gigi dan mulut yang diberikan penyuluhan ceramah sebesar $54,4 \%$ dan penyuluhan dengan pengisian teka-teki silang $68,2 \%$. Pengetahuan dan tingkat kebersihan gigi dan mulut untuk kelompok penyuluhan dengan pengisian teka-teki silang lebih efektif dibandingkan dengan kelompok ceramah.

Pengetahuan kesehatan gigi dan mulut adalah penting dalam membentuk sikap dan perilaku utuk sehat. Pengetahuan yang baik akan berdampak pada perilaku merawat kesehatan gigi dan mulut yang baik pula. ${ }^{10}$ Penyuluhan kesehatan gigi dan mulut adalah upaya-upaya yang dilakukan untuk merubah perilaku seseorang, kelompok orang atau masyarakat sehingga mempunyai pengetahuan, sikap dan kebiasaan untuk berperilaku untuk hidup sehat dibidang kesehatan gigi dan mulut. ${ }^{11}$ Hasil penelitian menunjukkan bahwa penyuluhan dengan ceramah terdapat perbedaan yang signifikan antara sebelum dan sesudah diberikan penyuluhan, baik pengetahuan maupun tingkat kebersihan gigi dan mulut.. Hasil analisis dengan menggunakan Uji Wilcoxon Signed Rank, terdpat perbedaan antara sebelum dan sesudah dengan $p<0,05$. Penelitian ini sejalan dengan hasil penelitian, ${ }^{8}$ dengan uji $t$ berpasangan menunjukkan $p$ yaitu $0,000(p<0,05)$ yaaitu terdapat perbedaan yang bermakna tingkat pengetahuan sebelum dan sesudah dengan ceramah dan demonstasi. Metode ceramah dan metode demonstrasi lebih efektif dalam meningkatkan pengetahuan dan kesehatan gigi dan mulut anak. Hasil penelitian pemberian penyuluhan dengan pengisian teka teki silang terdapat perbedaan yang signifikan antara sebelum dan sesudah diberikan penyuluhan, baik pengetahuan maupun tingkat kebersihan gigi dan mulut. Hasil analisis dengan menggunakan paired sampel test, terdapat perbedaan antara sebelum dan sesudah penyuluhan dengan $p<0,05$. Hasil analisis ini menunjukkan ada perbedaan yang signifikan pengetahuan dan tingkat kebersihan gigi dan mulut sebelum dan sesudah penyuluhan dengan pengisian teka-teki silang. Penelitian ini sejalan dengan penelitian (Wasgito dan Setiadarma, 2014) yang hasilnya sebanyak 21 anak 87,5\% dinyatakan lulus untuk pembelajaran siswa kelas VII SMP 2 Kalianget dengan menggunakan media perminan edukatif teka-teki silang.

Hasil analisis uji Efektifitas dengan persen dengan Rumus $\frac{A-B}{A} \times 100 \%$ maka terdapat perbedaan penyuluhan antara ceramah dan penyuluhan dengan pengisian teka teki silang yaitu sebelum ceramah 20,1\%, dan sebelum pemberian teka teki silang 22,0\%. Sedangkan peningkatan kebersihan gigi dan mulut sesudah ceramah $54,4 \%$, dan sesudah pemberian teka teki silang $68,2,0 \%$. Teka-teki silang merupakan permainan sederhana yang banyak dimainkan dari berbagai kalangan. Teka-teki silang akan membuat siswa semangat dan penasaran mencari jawaban. Sehingga pembelajaran dengan dengan media permainan tekateki silang akan membuat siswa lebih mengingat apa yang mereka pelajari melalui 
pengalaman belajar dengan menggunakan media teka-teki silang. Karena belajar dengan santai inilah yang dapat membuat siswa menjasi lebih paham dn mudh masuk dalam ingatan dengan materi yang sudah dipelajrinya.

\section{Kesimpulan}

Berdasarkan hasil penelitian dan pembahasan, dapat diambil simpulan bahwa penyuluhan dengan pengisian teka-teki silang lebih efektif meningkatkan pengetahuan dan meningkatkan kebersihan gigi dan mulut daripada penyuluhan dengan ceramah, yaitu penyuluhan dengan ceramah pengetahuan 20,1\% dan penyuluhan Teka-teki Silang 22,\%. Untuk peningkatan kebersihan gigi dan mulut penyuluhan dengan ceramah indeks plaknya $54,4 \%$ sedangkan penyuluhan dengan pengisian Teka-teki Silang indeks plaknya $68,2 \%$.

\section{Daftar Pustaka}

I. Putri, M. H., Herijulianti, E., \& Nurjannah, N. (20I0). Ilmu Pencegahan Penyakit Jaringan Keras dan pendukung Gigi. Buku Kedokteran. EGC. Jakarta.

2. Maharani, A. 2015. Berkumur dengan Daun Sirih membantu Menghilangkan Plak. Anggota Redaksi Medis dokter com.

3. KemenKes, R. I. 2013. Riset kesehatan dasar (Riskesdas) 2013. Jakarta: Badan Penelitian dan Pengembangan Kesehatan Kementrian Kesehatan Republik Indonesia.

4. Notoatmodjo, s, 2012. Promosi Kesehatan dan Perilaku Kesehatan. PT Rineka Cipta, Jakarta

5. Notoatmodjo, s, 20I0. Promosi Kesehatan dan Perilaku Kesehatan, PT Rineka Cipta, Jakarta

6. Ewles, L., Simnett, I. I994. Promosi Kesehatan Petunjuk Praktis. Gadjah Mada University Press, Yogyakarta.

7. Syah, M., 2003, Psikologi Pendidikan dengan Pendekatan Baru, Remaja Rosdakarya, Bandung.

8. Setiyawati D. Efektifitas Penyuluhan dengan Metode Ceramah dan Demonstrasi terhadap Peningkatan Pengetahuan tentang Kesehatan Gigi dan Mulut pada Anak di SDN Soka Kecamatan Poncowarno Kabupaten Kebumen. Skripsi. Semarang: STIKES Muhammadiyah Gombong.

9. Andi Wasgito Muhammad dan Setiadarma Wayan. 20I4. Pengembangan Media Permainan Edukatif Teka-Teki Silang (TTS) dalam Proses Pembelajaran Siswa Kelas VII SMP Negeri 2 Kalianget. Jurnal Seni Rupa, 2(3).36-43

I0. Neamatollahi H, Ebrahimi M, Talebi M, Ardabili MH, Kondori K. 20I I. Major differences in oral health knowledge and behavior in a group of Iranian preuniversity students: a cross-sectional study. Journal of Oral Science, 53 (2):177I84.

II. Kementerian Kesehatan RI. 2008. Pusat Promosi Kesehatan: Pengelolaan Media Promosi Kesehatan. Jakarta. 